\title{
Combined Beta-Agonists and Corticosteroids Do Not Inhibit Extracellular Matrix Protein Production In Vitro
}

\author{
Qi Ge, ${ }^{1,2}$ Maree H. Poniris, ${ }^{1,2}$ Lyn M. Moir, ${ }^{1,2}$ Judith L. Black, ${ }^{1,2}$ and Janette K. Burgess ${ }^{1,2}$ \\ ${ }^{1}$ Division of Cell Biology, Woolcock Institute of Medical Research, Sydney, P.O. Box M77, Missenden Road, NSW 2050, Australia \\ ${ }^{2}$ Discipline of Pharmacology, The University of Sydney, Sydney, NSW 2006, Australia
}

Correspondence should be addressed to Janette K. Burgess, janette.burgess@sydney.edu.au

Received 7 July 2011; Accepted 31 October 2011

Academic Editor: Peter Borger

Copyright (C) 2012 Qi Ge et al. This is an open access article distributed under the Creative Commons Attribution License, which permits unrestricted use, distribution, and reproduction in any medium, provided the original work is properly cited.

\begin{abstract}
Background. Persistent asthma is characterized by airway remodeling. Whereas we have previously shown that neither $\beta_{2}$-agonists nor corticosteroids inhibit extracellular matrix (ECM) protein release from airway smooth muscle (ASM) cells, the effect of their combination is unknown and this forms the rationale for the present study. Methods. ASM cells from people with and without asthma were stimulated with TGF $\beta 1(1 \mathrm{ng} / \mathrm{ml})$ with or without budesonide $\left(10^{-8} \mathrm{M}\right)$ and formoterol $\left(10^{-10}\right.$ and $\left.10^{-8} \mathrm{M}\right)$, and fibronectin expression and IL-6 release were measured by ELISA. Bronchial rings from nonasthmatic individuals were incubated with TGF $\beta 1(1 \mathrm{ng} / \mathrm{ml})$ with or without the drugs, and fibronectin expression was measured using immunohistochemistry. Results. Budesonide stimulated fibronectin deposition, in the presence or absence of TGF $\beta 1$, and this was partially reversed by formoterol $\left(10^{-8} \mathrm{M}\right)$ in both asthmatic and nonasthmatic cells. Budesonide and formoterol in combination failed to inhibit TGF $\beta$-induced fibronectin in either cell type. A similar pattern of expression of fibronectin was seen in bronchial rings. TGF $\beta 1$-induced IL- 6 release was inhibited by the combination of drugs. Conclusion. Current combination asthma therapies are unable to prevent or reverse remodeling events regulated by ASM cells.
\end{abstract}

\section{Introduction}

Airway remodeling, including alterations in the thickness of the basement membrane, an increase in the number of mucus producing cells, an increase in the number of blood vessels (angiogenesis), and a change in the extracellular matrix (ECM) protein profile and hypertrophy/hyperplasia resulting in an increase in the bulk of the airway smooth muscle (ASM), is now recognized as a hallmark feature of asthma. Little is known about the effectiveness of current asthma therapies upon these structural changes in the airways, particularly in the vicinity of the ASM.

We have previously reported that neither corticosteroids nor long-acting $\beta_{2}$-agonists (LABAs) alone are effective at preventing or reversing in vitro parameters of ASM-driven airway remodeling [1]. The critical question that remained was whether the combination of these two drug classes would be more effective.

Whilst the combination of inhaled corticosteroids and LABAs improves asthma control and lung function and decreases the frequency of asthma exacerbations compared to placebo or high doses of inhaled corticosteroids alone [2-6], few studies have examined their effectiveness at altering parameters of remodeling in vivo. One exception is the study by Orsida and colleagues who reported that the combination of LABAs and inhaled corticosteroids reduces blood vessel number [7]. Given our previous finding of the lack of effectiveness of these drugs singly in reducing parameters of airway remodeling, it was vital to assess their efficacy in combination.

Several studies have examined the in vitro effectiveness of combined corticosteroids and LABAs in fibroblasts with conflicting results. Goulet et al. found that corticosteroids and LABAs had opposing effects on matrix protein deposition in the presence of serum and their combination counteracted each other [8]. In contrast, also in fibroblasts, Descalzi et al. reported corticosteroids had significant antiproliferative effects and that combination with LABAs strengthened these effects [9]. Todorova et al. reported that corticosteroids reduced and the combination with LABAs 
TABle 1: Patient details.

\begin{tabular}{|c|c|c|c|c|c|}
\hline Patient no. & Age (yrs) & Sex & Disease & Source of tissue & Sample type \\
\hline 1 & 76 & Female & Chronic obstructive pulmonary disease & Endobronchial biopsy & ASM \\
\hline 2 & 43 & Female & Asthma & Endobronchial biopsy & ASM \\
\hline 3 & 26 & Male & Asthma & Endobronchial biopsy & ASM \\
\hline 4 & 66 & Male & Chronic obstructive pulmonary disease & Resection & ASM \\
\hline 5 & 22 & Male & Asthma & Endobronchial biopsy & ASM \\
\hline 6 & 38 & Female & Carcinoid (atypical) & Resection & ASM \\
\hline 7 & 46 & Female & Carcinoma & Resection & ASM \\
\hline 8 & 58 & Male & Emphysema & Explanted lungs & ASM \\
\hline 9 & 50 & Female & Asthma & Endobronchial biopsy & ASM \\
\hline 10 & 56 & Female & Emphysema & Explanted lungs & ASM \\
\hline 11 & 40 & Male & Asthma & Endobronchial biopsy & ASM \\
\hline 12 & 27 & Male & Asthma & Endobronchial biopsy & ASM \\
\hline 13 & 68 & Female & Carcinoma & Resection & ASM \\
\hline 14 & 55 & Male & Emphysema & Explanted lungs & ASM \\
\hline 15 & 64 & Female & Emphysema & Explanted lungs & ASM \\
\hline 16 & 21 & Male & Asthma & Endobronchial biopsy & ASM \\
\hline 17 & 25 & Female & Bronchiolitis Obliterans & Explanted lungs & Bronchial rings \\
\hline 18 & 48 & Female & Emphysema & Explanted lungs & Bronchial rings \\
\hline
\end{tabular}

ASM: airway smooth muscle.

abolished proteoglycan production induced by serum [10]. In the absence of serum, regardless of whether transforming growth factor $\beta$ (TGF $\beta$ ) was present or not, fluticasone increased fibronectin at both the mRNA and protein levels; however, it decreased tenascin- $C$ at both levels. Salmeterol did not affect fibronectin or tenascin-C nor did it alter the effect of fluticasone when the drugs were applied in combination [11].

Whilst we, and others, have begun elucidating the molecular mechanism underlying the synergistic effect of the combination of corticosteroids and LABAs in ASM cells $[12,13]$, the effect of the combined drugs on the release of ECM proteins from ASM cells remains to be investigated.

In this study, we hypothesized that the combination of corticosteroids and LABAs would be ineffective at inhibiting the production of ECM proteins in vitro. To investigate this hypothesis, we examined the effect of the combination of corticosteroids and LABAs in a well-characterized model of in vitro airway remodeling [1], namely, TGF $\beta$-induced fibronectin in human asthmatic and nonasthmatic ASM cells in vitro and in nonasthmatic bronchial rings ex vivo.

\section{Materials and Methods}

2.1. Cell Culture. Approval for all experiments with human lung was provided by the Human Ethics Committees of The University of Sydney and the Sydney South West Area Health Service. Asthmatic ASM was obtained from 7 patients (mean age $32.7 \pm 11.5$ years SD) either undergoing resection for lung transplantation or deep endobronchial biopsies. Nonasthmatic ASM was obtained from bronchial airways of 9 patients (mean age $58.6 \pm 11.6$ years SD) undergoing resection for either lung transplantation or carcinoma. The characteristics of the patients are listed in Table 1. Pure
ASM bundles were dissected free and grown as explants as previously described [13-15]. ASM cell characteristics were determined by light microscopy and immunofluorescence for the detection of $\alpha$-smooth muscle actin and calponin [16]. All experiments were performed with cells between passages 4 and 8 .

2.2. Airway Smooth Muscle Cell Treatment. ASM cells from 6 asthmatic and 8 nonasthmatic patients were seeded for 24 hours in 5\% fetal bovine serum (FBS) (JRH Biosciences, Melbourne, Australia) Dulbecco's Modified Eagle's Medium (DMEM) (SAFC Biosciences, Lenexa, KS) in the presence of $20 \mathrm{U} / \mathrm{mL}$ penicillin, $20 \mu \mathrm{g} / \mathrm{mL}$ streptomycin, and $2.5 \mu \mathrm{g} / \mathrm{mL}$ amphotericin B (Invitrogen, Heidelberg, Australia) at a density of $1 \times 10^{4}$ cells per $\mathrm{cm}^{2}$. Medium was then changed to $0.1 \%$ insulin transferrin selenium (ITS) (Invitrogen, Heidelberg, Australia) DMEM for 24 hours before addition of formoterol $(0.1$ and $10 \mathrm{nmol} / \mathrm{L})$ and budesonide $(0.1$ and $10 \mathrm{nmol} / \mathrm{L}$ ) alone or in combination as indicated 30 minutes prior to stimulation with TGF $\beta 1(1 \mathrm{ng} / \mathrm{mL})$ for the time periods described below. The effect of the drugs in unstimulated cells was assessed by omission of the TGF $\beta$ stimulation in cells maintained in $0.1 \%$ ITS. All of the drugs were dissolved in aqueous solutions.

\subsection{ELISAs}

2.3.1. Deposited ECM Protein ELISAs. ASM cells from 6 asthmatic and 6 nonasthmatic patients were seeded in 96 well plates and treated as described above for 48 hours. ECM free of cells was prepared by treatment with sterile hypotonic ammonium hydroxide [17-19]. Fibronectin was measured by ELISA as previously described [19] using an antibody to fibronectin (mouse antihuman plasma fibronectin $2 \mu \mathrm{g} / \mathrm{mL}$, 


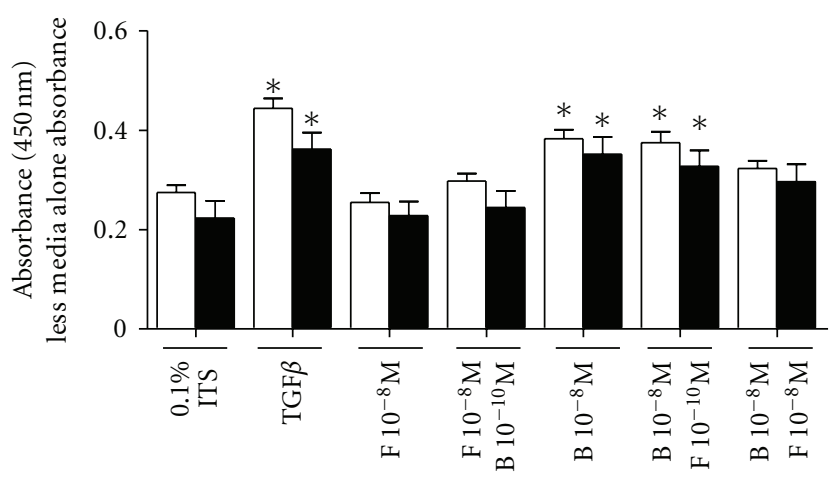

(a)

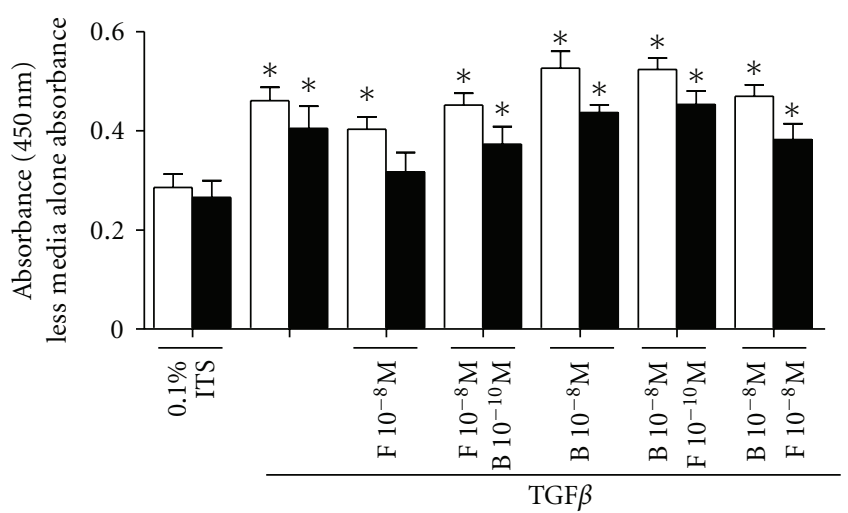

(b)

FIGURE 1: Effect of combined corticosteroids and LABAs on the deposition of fibronectin in the absence (a) or presence of TGF $\beta$ (b) for $48 \mathrm{hrs}$, respectively. Data are mean \pm SEM from $n=6$ asthmatic (black bars) and nonasthmatic (white bars) ASM cell lines. ${ }^{*}$ Significantly different from nondrug-treated control $P<0.05$. F: formoterol, B: budesonide.

clone 868A11, Chemicon, Temecula CA) and a purified mouse $\mathrm{IgG}_{1}$ isotype control $2 \mu \mathrm{g} / \mathrm{mL}$, clone MOPC-31C, (Becton and Dickinson Pharmingen, San Jose, CA).

2.3.2. IL-6 ELISAs. ASM cells from 6 asthmatic and 8 nonasthmatic patients were seeded in 24 well plates and treated as described above for 48 hours. Supernatants were collected in aliquots and stored at $-20^{\circ} \mathrm{C}$ until analysis. IL- 6 release was detected using an IL-6 ELISA kit according to the manufacturer's instructions (Duoset, Becton and Dickinson, San Jose, CA).

2.3.3. Soluble Fibronectin ELISAs. Supernatants collected as described above were also assayed for soluble fibronectin release using a Quantimatrix Human fibronectin ELISA kit according to the manufacturer's instructions (Chemicon International, Temecula, CA).

2.3.4. Immunohistochemistry. Human lung tissue was obtained from lung specimens resected for carcinoma or transplantation. Bronchial rings $(2-5 \mathrm{~mm}$ diameter and $3 \mathrm{~mm}$ in length) were dissected free from surrounding parenchymal tissue. The bronchial rings were incubated in treatments as described above. After 24 hours, tissues were frozen in optimal cutting temperature (OCT) embedding medium (Fronine Laboratory Supplies, Riverstone, Australia), sectioned on a cryostat and immunohistochemistry performed using mouse anti-fibronectin $(1 \mu \mathrm{g} / \mathrm{mL}$ Chemicon International, Temecula, CA) coupled with a horseradish peroxidase labeled polymer. To help identify the morphology of the tissue, hematoxylin and eosin (H\&E) staining was performed on adjacent sections. Full details of this method have been described previously [1].

2.3.5. Analysis of Data. For ECM ELISA data, results from duplicate wells from each individual subject were averaged and the absorbance from media alone subtracted before an overall mean and standard error of the mean (SEM) were obtained from asthmatic and nonasthmatic cells. Analysis of variance (ANOVA) repeated measures with bonferonni posttests or student's paired $t$-tests were performed on the results for ECM ELISAs where appropriate. In all cases a $P$ value of less than or equal to 0.05 was considered significant.

\section{Results}

3.1. Effect of Combined Corticosteroids and LABAs on Basal ECM Protein Deposition. Budesonide alone $\left(10^{-8} \mathrm{M}\right)$ induced fibronectin deposition in both asthmatic and nonasthmatic ASM cells (Figure 1), in agreement with our previous study [1]. The addition of formoterol $\left(10^{-8} \mathrm{M}\right.$ but not $10^{-10} \mathrm{M}$ ) abolished the induction of fibronectin by budesonide $10^{-10} \mathrm{M}$ and $10^{-8} \mathrm{M}$ (Figure $1(\mathrm{a})$ and Table 2).

3.2. Effect of Combined Corticosteroids and LABAs on TGF $\beta$ Stimulated ECM Protein Deposition. TGF $\beta$ induced the deposition of fibronectin from both asthmatic and nonasthmatic ASM cells, in agreement with our previous reports $[1,20,21]$ (Figure 1). The addition of formoterol $\left(10^{-10} \mathrm{M}\right.$ and $10^{-8} \mathrm{M}$ ) or budesonide $\left(10^{-8} \mathrm{M}\right.$ or $\left.10^{-10} \mathrm{M}\right)$, alone or in combination, did not significantly alter fibronectin deposition in the presence of TGF $\beta$ in either cell type.

\subsection{Effect of Combined Corticosteroids and LABAs on TGF $\beta$} Stimulated Soluble Fibronectin Release. The release of soluble fibronectin from asthmatic and nonasthmatic ASM cells was increased by TGF $\beta$ but the presence of the drugs, in any combination, did not alter the release of fibronectin (data not shown).

3.4. Effect of Combined Corticosteroids and LABAs on Basal IL6 Release. In nonasthmatic ASM cells, budesonide $\left(10^{-8} \mathrm{M}\right)$ alone significantly reduced the release of IL- 6 . The addition of formoterol $\left(10^{-10}\right.$ or $\left.10^{-8} \mathrm{M}\right)$ did not reverse this reduction (Figure 2(a) and Table 3). The release of IL-6 from asthmatic ASM cells was more variable but followed the same pattern. 
TABLE 2: Effect of combined corticosteroids and LABAs on basal and TGF $\beta$-stimulated ECM protein deposition.

\begin{tabular}{|c|c|c|c|c|c|c|c|c|}
\hline \multirow[t]{2}{*}{ Asthmatic } & & \multicolumn{3}{|c|}{ Alone } & \multirow[t]{2}{*}{ Nonasthmatic } & \multicolumn{3}{|c|}{ Alone } \\
\hline & & - & $\mathrm{F} 10^{-10} \mathrm{M}$ & $\mathrm{F} 10^{-8} \mathrm{M}$ & & - & $\mathrm{F} 10^{-10} \mathrm{M}$ & $\mathrm{F} 10^{-8} \mathrm{M}$ \\
\hline & - & & & $104.8 \pm 6.7$ & - & & & $92.3 \pm 2.5$ \\
\hline \multirow[t]{4}{*}{ Alone } & B $10^{-10} \mathrm{M}$ & & & $111.5 \pm 9.2$ & B $10^{-10} \mathrm{M}$ & & & $108.5 \pm 2.1$ \\
\hline & $\mathrm{B} 10^{-8} \mathrm{M}$ & $166.4 \pm 13.4^{*}$ & $154.8 \pm 13.0$ & $137.1 \pm 8.3$ & $\mathrm{~B} 10^{-8} \mathrm{M}$ & $140.5 \pm 7.4^{*}$ & $137.3 \pm 7.7$ & $117.9 \pm 4.4$ \\
\hline & \multicolumn{4}{|c|}{ TGF $\beta$ stimulated } & & \multicolumn{3}{|c|}{ TGF $\beta$ stimulated } \\
\hline & & - & $\mathrm{F} 10^{-10} \mathrm{M}$ & $\mathrm{F} 10^{-8} \mathrm{M}$ & & - & $\mathrm{F} 10^{-10} \mathrm{M}$ & $\mathrm{F} 10^{-8} \mathrm{M}$ \\
\hline \multirow{3}{*}{ TGF $\beta$ stimulated } & - & & & $78.3 \pm 2.5^{*}$ & - & & & $87.4 \pm 2.0^{*}$ \\
\hline & B $10^{-10} \mathrm{M}$ & & & $93.6 \pm 3.8$ & B $10^{-10} \mathrm{M}$ & & & $98.5 \pm 3.6$ \\
\hline & B $10^{-8} \mathrm{M}$ & $113.5 \pm 10.2$ & $116.0 \pm 8.1$ & $97.1 \pm 6.5$ & B $10^{-8} \mathrm{M}$ & $114.1 \pm 3.0^{*}$ & $114.2 \pm 2.8$ & $102.3 \pm 2.7$ \\
\hline
\end{tabular}

F: formoterol, B: budesonide.

Data are expressed as $\% 0.1 \%$ ITS for drugs alone and $\% \operatorname{TGF} \beta$ for TGF $\beta$-stimulated samples.

* significantly diff to $0.1 \%$ ITS or TGF $\beta P<0.05 . n=6$ asthmatic and 6 nonasthmatic.

TABLE 3: Effect of combined corticosteroids and LABAs on basal and TGF $\beta$-stimulated IL6 release.

\begin{tabular}{|c|c|c|c|c|c|c|c|c|}
\hline \multirow[t]{2}{*}{ Asthmatic } & & \multicolumn{3}{|c|}{ Alone } & \multirow[t]{2}{*}{ Nonasthmatic } & \multicolumn{3}{|c|}{ Alone } \\
\hline & & - & $\mathrm{F} 10^{-10} \mathrm{M}$ & $\mathrm{F} 10^{-8} \mathrm{M}$ & & - & $\mathrm{F} 10^{-10} \mathrm{M}$ & $\mathrm{F} 10^{-8} \mathrm{M}$ \\
\hline \multirow{5}{*}{ Alone } & - & & & $275.6 \pm 71.4$ & - & & & $224.0 \pm 68.2$ \\
\hline & B $10^{-10} \mathrm{M}$ & & & $208.3 \pm 54.8$ & B $10^{-10} \mathrm{M}$ & & & $181.5 \pm 51.6$ \\
\hline & $\mathrm{B} 10^{-8} \mathrm{M}$ & $31.9 \pm 12.7$ & $54.1 \pm 22.5$ & $166.6 \pm 48.7$ & $\mathrm{~B} 10^{-8} \mathrm{M}$ & $23.35 \pm 2.5$ & $78.13 \pm 47.5$ & $187.1 \pm 112.7$ \\
\hline & \multicolumn{4}{|c|}{ TGF $\beta$ stimulated } & & \multicolumn{3}{|c|}{ TGF $\beta$ stimulated } \\
\hline & & 一 & $\mathrm{F} 10^{-10} \mathrm{M}$ & $\mathrm{F} 10^{-8} \mathrm{M}$ & & - & $\mathrm{F} 10^{-10} \mathrm{M}$ & $\mathrm{F} 10^{-8} \mathrm{M}$ \\
\hline \multirow{3}{*}{ TGF $\beta$ stimulated } & - & & & $68.2 \pm 9.2$ & - & & & $74.1 \pm 9.5$ \\
\hline & B $10^{-10} \mathrm{M}$ & & & $55.8 \pm 7.9$ & B $10^{-10} \mathrm{M}$ & & & $58.78 \pm 5.4$ \\
\hline & $\mathrm{B} 10^{-8} \mathrm{M}$ & $13.7 \pm 3.6$ & $13.7 \pm 4.0$ & $21.1 \pm 5.5$ & B $10^{-8} \mathrm{M}$ & $20.0 \pm 1.9$ & $17.3 \pm 2.9$ & $17.6 \pm 2.9$ \\
\hline
\end{tabular}

F: formoterol, B: budesonide.

Data are expressed as mean \pm SEM $\% 0.1 \%$ ITS for drugs alone and $\%$ TGF $\beta$ for TGF $\beta$-stimulated samples. $n=6$ asthmatic and 8 nonasthmatic.

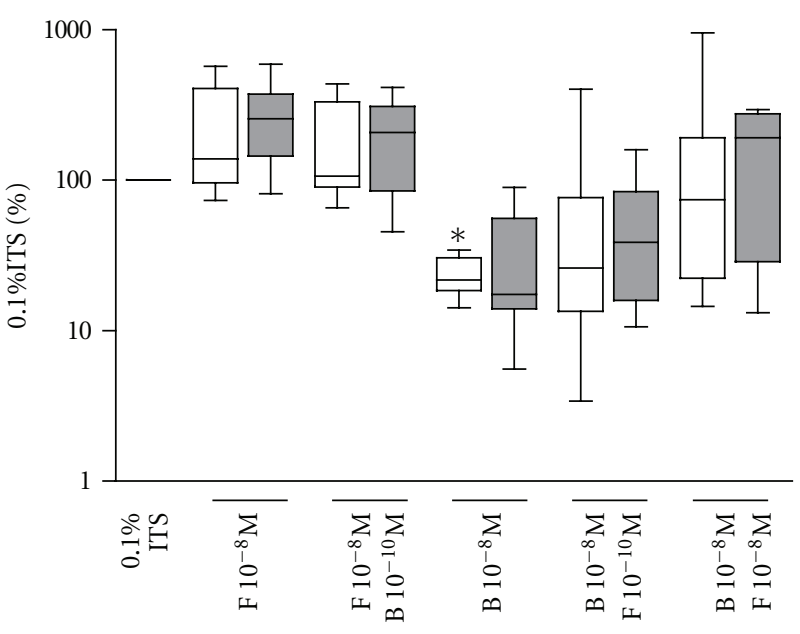

(a)

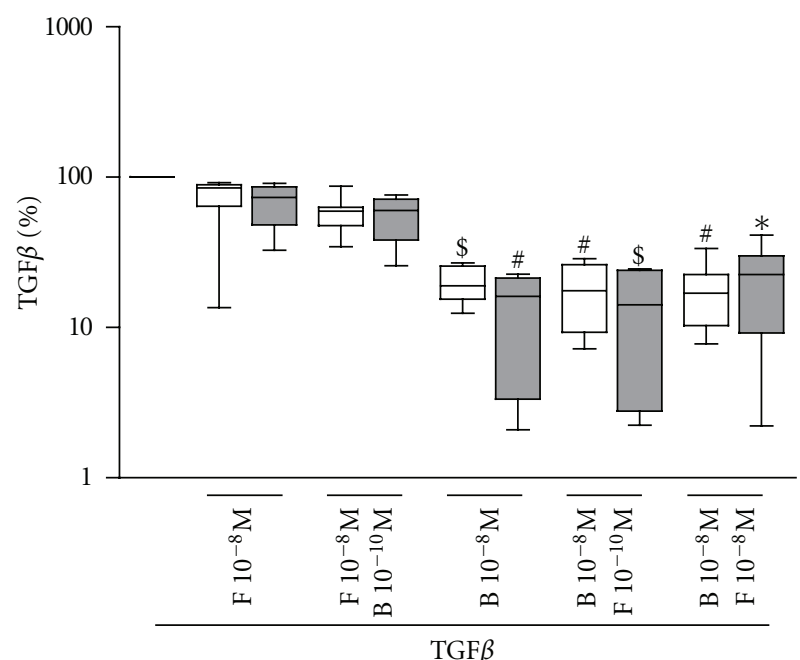

(b)

FIGURE 2: Effect of combined corticosteroids and LABAs on the release of IL-6 in the absence (a) or presence of TGF $\beta$ (b) for 48 hrs respectively. Data are mean \pm SEM from $n=6$ asthmatic (grey boxes) and $n=8$ nonasthmatic (white boxes) ASM cell lines. Significantly different from nondrug-treated control ${ }^{*} P<0.05,{ }^{\#} P<0.005,{ }^{\$} P<0.001$. F: formoterol, B: budesonide. 


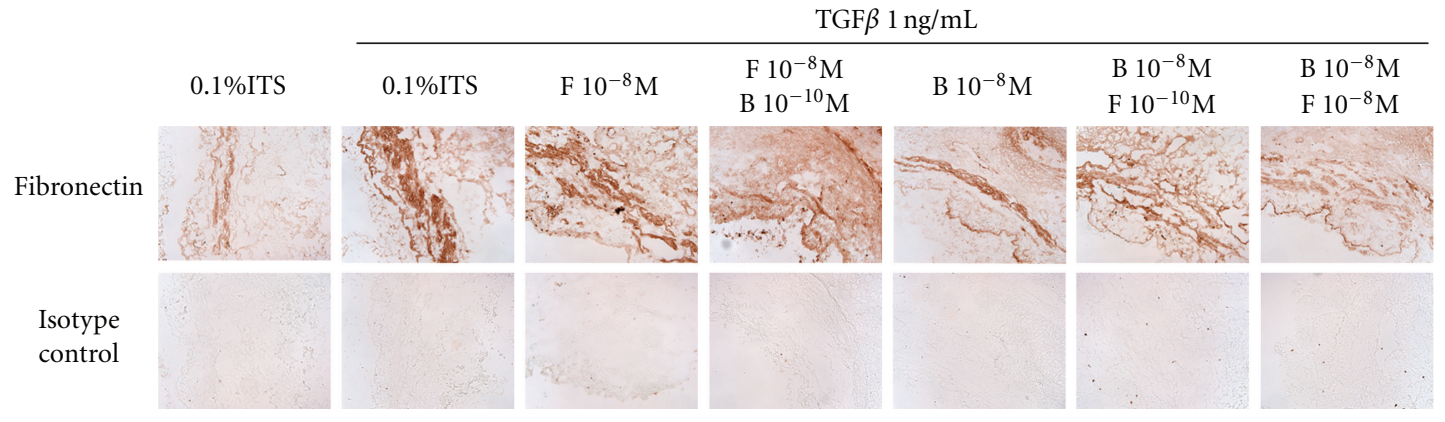

FIGURE 3: Effect of combined corticosteroids and LABA on TGF $\beta$-induced fibronectin in nonasthmatic bronchial rings. Immunohistochemical detection of fibronectin (brown staining) basally or following stimulation with TGF $\beta$ in the presence or absence of drugs in nonasthmatic tissue sections.

3.5. Effect of Combined Corticosteroids and LABAs on TGF $\beta$ Stimulated IL-6 Release. In both cell types, TGF $\beta$ significantly induced the release of IL- 6 . Budesonide reduced the release of IL- 6 even in the presence of TGF $\beta$ in both cell types (Figure 2(b) and Table 3). Once again, formoterol $\left(10^{-10}\right.$ and $10^{-8} \mathrm{M}$ ) did not reverse the inhibitory effect of budesonide (asthmatic $13.66 \pm 4.0$ and $21.08 \pm 5.5$, nonasthmatic 17.34 \pm 2.9 and $17.55 \pm 2.9 \%$ of TGF $\beta$ ) (Figure 2(b)).

3.6. Effect of Combined Corticosteroids and LABAs on Fibronectin Expression in Bronchial Tissue Rings. To examine the effectiveness of the combination of corticosteroids and LABAs on ECM deposition in the whole airway, we used our ex vivo bronchial ring model $[1,20]$. Bronchial rings from two nonasthmatic individuals stimulated with TGF $\beta$ showed increased deposition of fibronectin, in agreement with our previous findings $[1,20]$. Neither formoterol nor budesonide alone, or in combination, reduced the TGF $\beta$ induced fibronectin deposition (Figure 3 ).

\section{Discussion}

Our previous work demonstrated that neither long-acting beta agonists nor corticosteroids reduced the release of ECM proteins from ASM cells. The question remained as to whether the combination of these two therapeutic drug classes might be more effective. The results of the current study with formoterol and budesonide demonstrate that this is not the case, regardless of whether the cells were derived from asthmatic or nonasthmatic subjects. Moreover, in bronchial rings stimulated with $\mathrm{TGF} \beta$, fibronectin deposition was not reduced by formoterol, budesonide, nor their combination.

There are many examples of the efficacy of combined LABAs and corticosteroids in both in vivo $[5,22]$ and in vitro $[13,23-25]$ studies. There are very few reports, however, of the modulation of remodeling parameters by these drugs, although the combination of LABAs and inhaled corticosteroids does reduce angiogenesis-one of the features of remodeling [7]. In addition, we have reported a synergistic inhibition of ASM proliferation when these drugs are studied in combination [13]. However, budesonide and salbutamol, alone or in combination, had no effect on collagen fiber tractional remodeling as ASM cells migrated through collagen gels [26]. Descalzi et al. [9] found that the combination of beclomethasone dipropionate (BDP) with either a short or long-acting beta agonist decreased fibronectin production induced by basic fibroblast growth factor, and that this effect was greater than with BDP alone. Their study was carried out in fibroblasts stimulated with basic fibroblast growth factor, as opposed to smooth muscle cells stimulated with TGF $\beta$ in the current study, and this may be the basis for the differences observed. Again, in fibroblasts, corticosteroids in the presence of serum increased ECM deposition, which we also found in ASM cells, but LABAs decreased ECM deposition and the net result of the combination was simply additive [8]. In contrast, Degen et al. found, in fibroblasts, that fluticasone increased fibronectin but decreased tenascin$\mathrm{C}$ mRNA and protein induced by FBS, TGF $\beta$, or in the absence of stimulation. Under these experimental conditions salmeterol did not influence the fluticasone effects [11]. We also examined the effect of corticosteroids and LABAs alone and in combination on TGF $\beta$-induced soluble, as opposed to matrix-associated, fibronectin release but again these interventions were without effect in either asthmatic or nonasthmatic cells. To our knowledge, there are no previous reports examining the effect of combination therapy in asthmatic ASM.

A consistent finding from our laboratory has been the increase in release of ECM proteins from ASM in response to corticosteroids. Beclomethasone increased release of fibronectin from ASM [19] and this effect has also been reported by Goulet et al. and Degen et al. in human airway fibroblasts using several corticosteroids $[8,11]$. This is consistent with the fact that budesonide increased fibronectin release from ASM cells derived from both asthmatic and nonasthmatic subjects in our current study, and furthermore this occurred whether or not cells were stimulated with TGF $\beta$. Interestingly, formoterol was able to attenuate budesonide-induced ECM fibronectin deposition even though alone it was without effect. The differential response of fibroblasts to fluticasone in relation to the production of fibronectin and tenascin-C observed by Degen et al. [11] suggests that the individual ECM proteins may respond 
differently to therapeutic intervention. Therefore, caution should be taken in interpreting the results of this in vitro study as a global representation of the effectiveness of current therapies on altering parameters of airway remodeling.

Although we found in the present study that the combination of LABAs and corticosteroids did not decrease fibronectin release, corticosteroids, as previously reported $[1,27]$, inhibited IL-6 release from the ASM cells. Baouz et al. reported that in (myo) fibroblasts, salmeterol inhibited IL-6 release, and this was amplified by the addition of low concentrations of fluticasone dipropionate [28]. Others have found, also in fibroblasts, that corticosteroids inhibited and LABAs had no effect on IL-6 release and the effect of the combination was that of corticosteroids alone [8]. In contrast, IL- 6 release from ASM is increased by $\beta_{2}$-agonists in both asthmatic [1] and nonasthmatic cells [1, 29], and our findings in the current study confirm this.

The study of cells in culture is associated with limitations, and this is where we find the bronchial ring preparation a useful model. It enables us to observe, in an "intact" airway, changes in ECM proteins $[1,17]$ and cytokine deposition $[15,30]$ in response to profibrotic stimuli such as TGF $\beta$ and, in addition, to investigate the effects of intervention with relevant therapeutic agents such as LABAs and corticosteroids. Here we confirmed our previous findings [1] that neither LABAs nor corticosteroids alone decreased fibronectin deposition in response to $\operatorname{TGF} \beta$ and extended them to include the combination of the two drug classes which were without effect. In contrast, we have previously reported that the phosphodiesterase inhibitor roflumilast abolished TGF $\beta$-induced fibronectin deposition [1].

In summary, in our cell and tissue models of ECM protein deposition, we investigated whether the combination of a LABA and a corticosteroid would be more effective in inhibiting or reversing TGF $\beta$-induced fibronectin release. This was not the case either in cells derived from asthmatic or nonasthmatic volunteers, or in intact bronchial rings. Airway remodeling is detrimental in the pathophysiology of asthma, and ECM protein deposition is a major component of said remodeling; therefore, these results highlight the need for further development of agents to reverse or prevent parameters of airway remodeling.

\section{Acknowledgments}

The authors acknowledge the collaborative effort of the cardiopulmonary transplant team and the pathologists at St Vincent's Hospital, Sydney, and the thoracic physicians and pathologists at Royal Prince Alfred Hospital, Concord Hospital, and Strathfield Private Hospital and Rhodes Pathology, Sydney. They also acknowledge the contribution of Drs Gregory King and Melissa Baraket at the Woolcock Institute of Medical Research and Professor Iven Young at Royal Prince Alfred Hospital for supplying the asthmatic biopsies, and Joanne Thompson, Sarah Boustany and Vanessa Young for excellent technical assistance. This work was supported by the National Health and Medical Research Council, Australia. J. K. Burgess is supported by an NH\&MRC R. Douglas
Wright Fellowship no. 402835 and J. L. Black by a NH\&MRC Senior Principal Research Fellowship no. 571098.

\section{References}

[1] J. K. Burgess, B. G. G. Oliver, M. H. Poniris et al., "A phosphodiesterase 4 inhibitor inhibits matrix protein deposition in airways in vitro," Journal of Allergy and Clinical Immunology, vol. 118, no. 3, pp. 649-657, 2006.

[2] I. R. Greenstone, M. N. Ni Chroinin, V. Masse et al., "Combination of inhaled long-acting $\beta_{2}$-agonists and inhaled steroids versus higher dose of inhaled steroids in children and adults with persistent asthma," Cochrane Database of Systematic Reviews, vol. 19, no. 4, Article ID CD005533, 2005.

[3] M. N. Chroinin, I. R. Greenstone, A. Danish et al., "Longacting $\beta_{2}$-agonists versus placebo in addition to inhaled corticosteroids in children and adults with chronic asthma," Cochrane Database of Systematic Reviews, vol. 19, no. 4, Article ID CD005535, 2005.

[4] A. P. Greening, P. W. Ind, M. Northfield, and G. Shaw, "Added salmeterol versus higher-dose corticosteroid in asthma patients with symptoms on existing inhaled corticosteroid. Allen \& Hanburys Limited UK Study Group," The Lancet, vol. 344, no. 8917, pp. 219-224, 1994.

[5] R. A. Pauwels, C.-G. Löfdahl, D. S. Postma et al., "Effect of inhaled formoterol and budesonide on exacerbations of asthma. Formoterol and Corticosteroids Establishing Therapy (FACET) International Study Group," The New England Journal of Medicine, vol. 337, no. 20, pp. 1405-1411, 1997.

[6] A. Woolcock, B. Lundback, N. Ringdal, and L. A. Jacques, "Comparison of addition of salmeterol to inhaled steroids with doubling of the dose of inhaled steroids," American Journal of Respiratory and Critical Care Medicine, vol. 153, no. 5, pp. 1481-1488, 1996.

[7] B. E. Orsida, C. Ward, X. Li et al., "Effect of a long-acting $\beta_{2}$ agonist over three months on airway wall vascular remodeling in asthma," American Journal of Respiratory and Critical Care Medicine, vol. 164, no. 1, pp. 117-121, 2001.

[8] S. Goulet, M. P. Bihl, F. Gambazzi, M. Tamm, and M. Roth, "Opposite effect of corticosteroids and long-acting $\beta_{2}$ - agonits on serum- and TGF- $\beta_{1}$-induced extracellular matrix deposition by primary human lung fibroblasts," Journal of Cellular Physiology, vol. 210, no. 1, pp. 167-176, 2007.

[9] D. Descalzi, C. Folli, G. Nicolini et al., "Anti-proliferative and anti-remodelling effect of beclomethasone dipropionate, formoterol and salbutamol alone or in combination in primary human bronchial fibroblasts," Allergy, vol. 63, no. 4, pp. 432437, 2008.

[10] L. Todorova, E. Gürcan, A. Miller-Larsson, and G. WestergrenThorsson, "Lung fibroblast proteoglycan production induced by serum is inhibited by budesonide and formoterol," American Journal of Respiratory Cell and Molecular Biology, vol. 34, no. 1, pp. 92-100, 2006.

[11] M. Degen, S. Goulet, J. Ferralli, M. Roth, M. Tamm, and R. Chiquet-Ehrismann, "Opposite effect of fluticasone and salmeterol on fibronectin and tenascin-C expression in primary human lung fibroblasts," Clinical \& Experimental Allergy, vol. 39, no. 5, pp. 688-689, 2009.

[12] M. Kaur, J. E. Chivers, M. A. Giembycz, and R. Newton, "Long-acting $\beta_{2}$-adrenoceptor agonists synergistically enhance glucocorticoid-dependent transcription in human airway epithelial and smooth muscle cells," Molecular Pharmacology, vol. 73, no. 1, pp. 203-214, 2008. 
[13] M. Roth, P. R. Johnson, J. J. Rüdiger et al., "Interaction between glucocorticoids and $\beta_{2}$ agonists on bronchial airway smooth muscle cells through synchronised cellular signalling," The Lancet, vol. 360, no. 9342, pp. 1293-1299, 2002.

[14] P. R. Johnson, M. Roth, M. Tamm et al., "Airway smooth muscle cell proliferation is increased in asthma," American Journal of Respiratory and Critical Care Medicine, vol. 164, no. 3, pp. 474-477, 2001.

[15] J. K. Burgess, P. R. Johnson, Q. Ge et al., "Expression of connective tissue growth factor in asthmatic airway smooth muscle cells," American Journal of Respiratory and Critical Care Medicine, vol. 167, no. 1, pp. 71-77, 2003.

[16] W. Durand-Arczynska, N. Marmy, and J. Durand, "Caldesmon, calponin and $\alpha$-smooth muscle actin expression in subcultured smooth muscle cells from human airways," Histochemistry, vol. 100, no. 6, pp. 465-471, 1993.

[17] P. R. Johnson, J. K. Burgess, Q. Ge et al., "Connective tissue growth factor induces extracellular matrix in asthmatic airway smooth muscle," American Journal of Respiratory and Critical Care Medicine, vol. 173, no. 1, pp. 32-41, 2006.

[18] P. R. Johnson, J. K. Burgess, P. A. Underwood et al., "Extracellular matrix proteins modulate asthmatic airway smooth muscle cell proliferation via an autocrine mechanism," Journal of Allergy and Clinical Immunology, vol. 113, no. 4, pp. 690696, 2004.

[19] P. R. Johnson, J. L. Black, S. Carlin, Q. Ge, and P. A. Underwood, "The production of extracellular matrix proteins by human passively sensitized airway smooth-muscle cells in culture: the effect of beclomethasone," American Journal of Respiratory and Critical Care Medicine, vol. 162, no. 6, pp. 2145-2151, 2000.

[20] P. R. Johnson, J. K. Burgess, Q. Ge et al., "Connective tissue growth factor and transforming growth factor B induces extracellular matrix in asthmatic airway smooth muscle," American Journal of Respiratory and Critical Care Medicine, vol. 2, p. A250, 2005.

[21] L. M. Moir, J. K. Burgess, and J. L. Black, "Transforming growth factor $\beta_{1}$ increases fibronectin deposition through integrin receptor $\alpha_{5} \beta_{1}$ on human airway smooth muscle," Journal of Allergy and Clinical Immunology, vol. 121, no. 4, pp. 1034-1039.e4, 2008.

[22] S. Shrewsbury, S. Pyke, and M. Britton, "Meta-analysis of increased dose of inhaled steroid or addition of salmeterol in symptomatic asthma (MIASMA)," British Medical Journal, vol. 320, no. 7246, pp. 1368-1373, 2000.

[23] L. Pang and A. J. Knox, "Synergistic inhibition by $\beta_{2}$-agonists and corticosteroids on tumor necrosis factor- $\alpha$-induced interleukin-8 release from cultured human airway smooth-muscle cells," American Journal of Respiratory Cell and Molecular Biology, vol. 23, no. 1, pp. 79-85, 2000.

[24] L. Pang and A. J. Knox, "Regulation of TNF- $\alpha$-induced eotaxin release from cultured human airway smooth muscle cells by $\beta_{2}$-agonists and corticosteroids," The FASEB Journal, vol. 15, no. 1, pp. 261-269, 2001.

[25] F. M. Spoelstra, D. S. Postma, H. Hovenga, J. A. Noordhoek, and H. F. Kauffman, "Additive anti-inflammatory effect of formoterol and budesonide on human lung fibroblasts," Thorax, vol. 57, no. 3, pp. 237-241, 2002.

[26] J. E. Bourke, X. Li, S. R. Foster et al., "Collagen remodelling by airway smooth muscle is resistant to steroids and $\beta 2$-agonists," European Respiratory Journal, vol. 37, no. 1, pp. 173-182, 2011.

[27] M. Roth, P. R. Johnson, P. Borger et al., "Dysfunctional interaction of $\mathrm{C} / \mathrm{EBP} \alpha$ and the glucocorticoid receptor in asthmatic bronchial smooth-muscle cells," The New England Journal of Medicine, vol. 351, no. 6, pp. 560-574, 2004.

[28] S. Baouz, J. Giron-Michel, B. Azzarone et al., "Lung myofibroblasts as targets of salmeterol and fluticasone propionate: inhibition of $\alpha$-SMA and NF- $\kappa \mathrm{B}$," International Immunology, vol. 17, no. 11, pp. 1473-1481, 2005.

[29] A. J. Ammit, L. M. Moir, B. G. Oliver et al., "Effect of IL-6 trans-signaling on the pro-remodeling phenotype of airway smooth muscle," American Journal of Physiology, vol. 292, no. 1, pp. L199-L206, 2007.

[30] J. K. Burgess, Q. Ge, M. H. Poniris et al., "Connective tissue growth factor and vascular endothelial growth factor from airway smooth muscle interact with the extracellular matrix," American Journal of Physiology, vol. 290, no. 1, pp. L153-L161, 2006. 


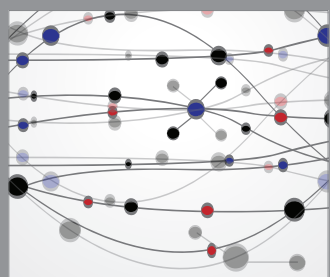

The Scientific World Journal
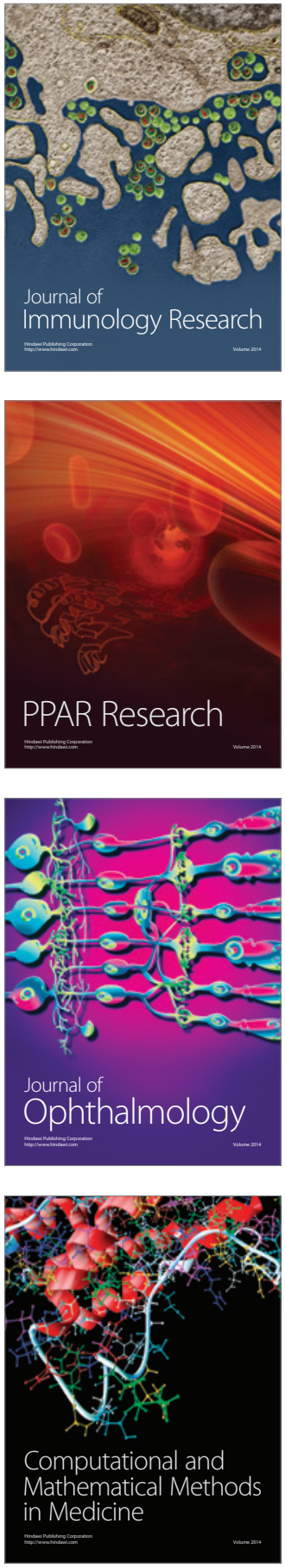

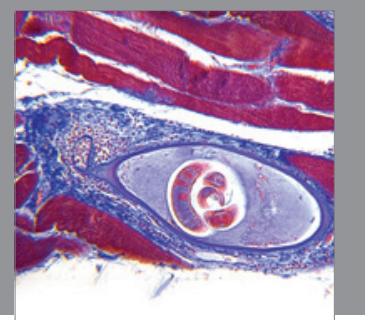

Gastroenterology

Research and Practice
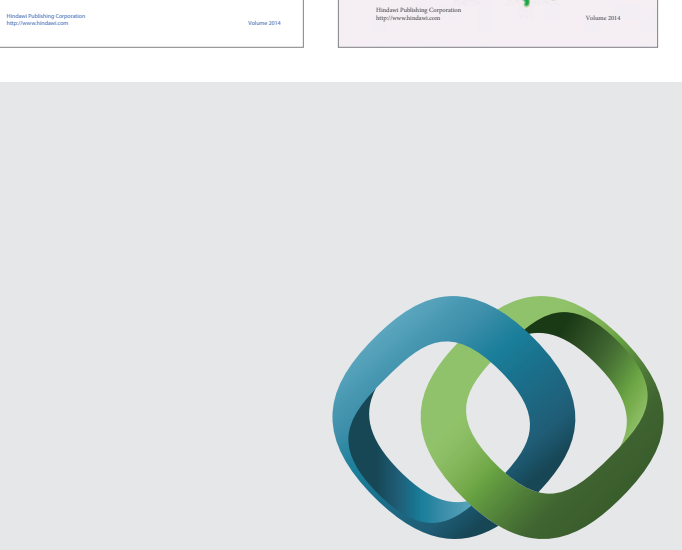

\section{Hindawi}

Submit your manuscripts at

http://www.hindawi.com
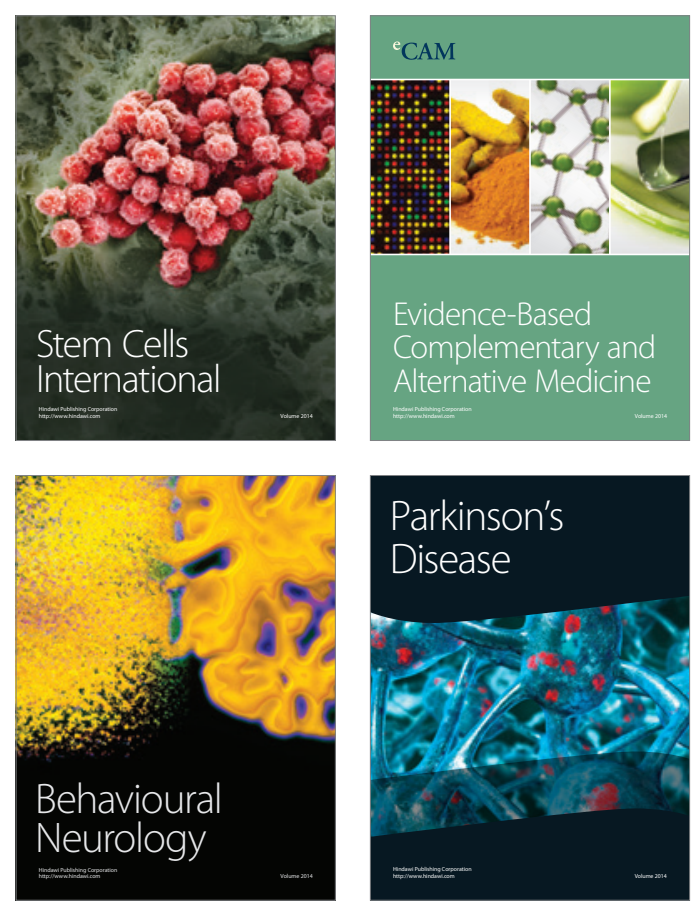

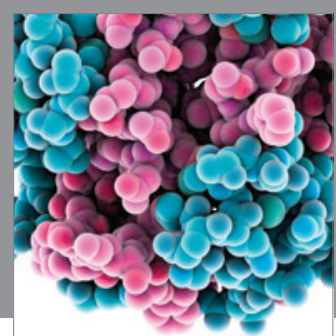

Journal of
Diabetes Research

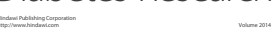

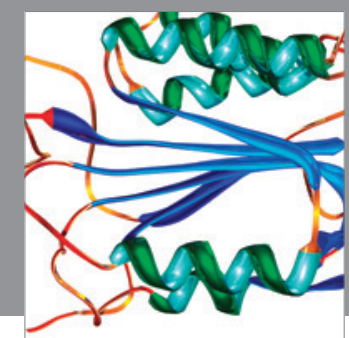

Disease Markers
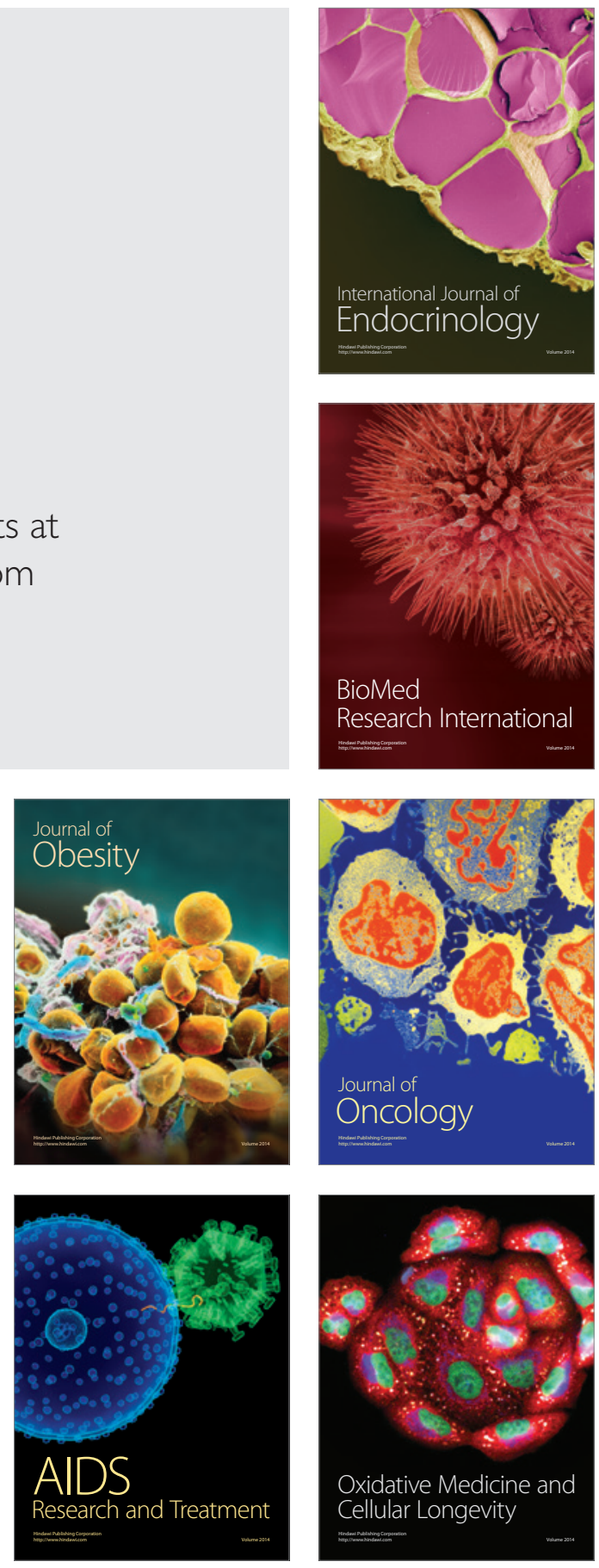